\title{
Glucose induces early growth response gene (Egr-1) expression in pancreatic beta cells
}

\author{
K. Josefsen ${ }^{1}$, L. R. Sørensen ${ }^{1}$, K. Buschard ${ }^{1}$, M. Birkenbach ${ }^{2}$ \\ ${ }^{1}$ Bartholin Institutet, Kommunehospitalet, Copenhagen, Denmark \\ ${ }^{2}$ Majorie B. Kovler Viral Oncology Laboratory, University of Chicago, Chicago, Illinois, USA
}

\begin{abstract}
Summary A copy deoxyribonucleic acid (cDNA) clone of the immediate early growth response gene, egr-1 (Krox-24, Zif268, NGFI-1), was isolated through subtractive hybridization screening to identify glucose-induced genes in pancreatic beta cells. Glucose rapidly and transiently induced egr-1 mRNA in the SV40-transformed murine beta-cell line, MIN6. Glucose also increased egr-1 mRNA expression in INS-1, $\beta$ TC3 and RINm5F beta-cell lines, although with different kinetics. Expression of the 82 $\mathrm{kDa}$ Egr-1 protein was induced both in MIN6 cells stimulated with glucose in vitro and in primary rat islet cells stimulated in vivo or in vitro. This response is unique to beta cells since glucose did not affect egr-1 expression in NIH-3T3 fibroblasts or glucosesensitive hepatocytes. In beta cells egr-1 induction is specifically associated with insulin secretion, as it was not observed after stimulation with serum or in-
\end{abstract}

sulin but was elicited by insulin secretagogues, including membrane depolarizing agents and cAMP agonists. Moreover, induction of egr- 1 by glucose was inhibited by EDTA, indicating dependence on influx of extracellular $\mathrm{Ca}^{2+}$. Other immediate early response genes, $c$-fos and junB, were also induced following glucose stimulation with kinetics similar to egr-1, whereas $c$-jun and junD expression were not affected. Since the zinc-finger protein encoded by egr-1 is highly homologous to transcription factors that control expression of glucose-regulated genes in yeast, Egr-1 could mediate delayed adaptive responses of beta cells to sustained glucose stimulation through transcriptional regulation. [Diabetologia (1999) 42: 195-203]

Keywords Glucose stimulation, beta-cell line, MIN6, transcription factor, Egr-1.
Glucose homeostasis is maintained by beta cells of pancreatic islets through precisely regulated release of insulin from preformed granules. To maintain constant intracellular insulin stores while meeting wide physiological variations in demand, insulin synthesis is modulated in parallel with secretion rates [1]. Im-

Received: 19 March 1998 and in revised form: 10 June 1998

Corresponding author: K. Josefsen, MD, PhD, Bartholin Institutet, Kommunehospitalet, DK-1399 Copenhagen K, Denmark

Abbreviations: egr-1, Early growth response gene; egr-1, early growth response protein; cDNA, copy deoxyribonucleic acid; GLUT-2, glucose transporter 2; IBMX, isobutylmethylxanthine; IPF-1, insulin promoter factor 1; MAP, mitogen-activated protein; TPA, phorbol 12-myristate 13-acetate; TSH, thyroid stimulating hormone. mediately following glucose stimulation, synthesis is primarily augmented through enhanced translation [2] and decreased degradation of existing insulin mRNAs [3]. Glucose also induces delayed responses that are manifested several hours after stimulation [4] by increasing insulin gene transcription [5] and expression of other genes involved in beta-cell function. Increased gene expression of glucose transporter 2 (GLUT-2) [6], pyruvate kinase [7], acetyl-coenzyme A-carboxylase [8], and $64 \mathrm{kDa}$ glutamic acid decarboxylase (GAD65) [9] have been observed in primary rat islets in vitro and in rodent insulin-producing tumour cell lines following exposure to glucose. Together these changes comprise a delayed adaptive response that could be necessary to meet increased metabolic and secretory demands during extended or repeated periods of hyperglycaemia. 
Mechanisms regulating glucose-activated transcription are only partly understood. Immediate glucose effects on insulin transcription in rodents have been attributed to glucose-dependent activation of the constitutively expressed islet-cell-specific transcription factor, insulin promoter factor 1 (IPF-1) and factors that bind $\mathrm{E} 1$ and $\mathrm{C} 1$ control elements [10-12]. Activity of the insulin upstream factor 1 (IUF1) complex, which may comprise the human equivalent of rodent IPF-1, is also glucose-dependent [13]. Increased expression of acetyl-coenzyme A-carboxylase results in part from glucose-induced binding of the ubiquitous stimulating protein 1 (Sp1) factor to glucose-response promoter elements [14]. Factors regulating glucose-induced transcription of most other genes, however, are still largely not known.

The relevance of glucose-regulated transcription has not been directly shown. Considerable evidence implicates, however, altered gene expression and transcription factor activity in beta-cell dysfunction. Loss of IPF-1 in hyperglycaemic rats correlates closely with diminished beta-cell insulin secretion in response to a glucose challenge [15]. Similarly, prolonged in vitro propagation of HIT-T15 cells in a high glucose medium results in reduced responsiveness which has been attributed to loss of IPF-1 expression [16]. Development of diabetes in Zucker diabetic fatty (ZDF) rats is associated with reduced expression of the transcription factor ISLET-1 [17], as well as several other genes, including glucokinase, mitochondrial glycerol-3-phosphate dehydrogenase, voltage-dependent $\mathrm{Ca}^{2+}$ - and $\mathrm{K}^{+}$-channels, $\mathrm{Ca}^{2+}$ ATPase and GLUT-2. Together these results suggest that the ability to modulate transcription in response to glucose could be necessary for normal beta-cell function.

To investigate further the effects of glucose on beta-cell gene transcription we have used subtraction cloning to identify genes induced by glucose stimulation. Using this approach, we have isolated a clone encoding the zinc-finger transcription factor Egr-1. Experiments reported here indicate that early growth response gene-1 (egr-1) expression is specifically and transiently upregulated in beta-cell lines and primary islet cells in response to glucose and other secretagogues. This is the first time specific induction of transcription factor expression in response to glucose has been shown in beta-cells. In view of its close homology with transcription factors that regulate carbohydrate metabolism in yeast, Egr-1 could mediate other delayed transcriptional changes and play a pivotal role in adaptive responses to sustained glucose stimulation. Moreover, these results suggest that target genes transcriptionally regulated by Egr-1 could be important in normal beta-cell function.

\section{Materials and methods}

Reagents. Thyrotropin, thyroid stimulating hormone (TSH) was from Armour Pharmaceuticals (Rhône Poulenc, Courbevoie, France), insulin a gift from Novo Nordisk (Bagsvœrd, Denmark) and Rp-cAMPS from BioLog Life Science Institute (Bremen, Germany). Phorbol 12-myristate 13-acetate (TPA), EDTA, ionomycin, isobutylmethylxantine (IBMX), forskolin, arginine, $\mathrm{rA} \cdot \mathrm{rU}$, dextran sulphate and okadaic acid were from Sigma (St. Louis, MO., USA).

Cell line cultures. The SV40-transformed murine beta-cell lines, MIN6 [18] and $\beta$ TC3 [19] were cultured in 90\% DMEM ( $22.5 \mathrm{mmol} / \mathrm{l}$ glucose) supplemented with $10 \%$ fetal bovine serum (FBS, Life Technologies, Gaithersburg, MD., USA). Hamster HIT-T15 [20], rat RINm5F [4] and INS-1 [19] insulinoma cell lines were maintained in 90\% RPMI 1640 (11 mmol/l glucose), 10\% FBS with necessary additives [19]. 3 T3 fibroblasts (ATCC) were grown in $90 \%$ DMEM (22.5 mmol/1 glucose), $10 \%$ donor calf serum (Life Technologies). Human HepG 2 hepatoma cells were grown in $90 \%$ RPMI 1640, $10 \%$ FBS. All cells were routinely tested for mycoplasma and were consistently negative.

Primary cell cultures. Primary islets of Langerhans were isolated from adult male Lewis rats by standard collagenase digestion. For in vitro stimulation experiments, islets were initially incubated for $24 \mathrm{~h}$ in $90 \%$ RPMI 1640 (11 mmol/l glucose), $10 \% \mathrm{FBS}$, followed by $24 \mathrm{~h}$ in $90 \%$ glucose-free-RPMI, $10 \%$ dialysed FBS, supplemented with $2.8 \mathrm{mmol} / \mathrm{l}$ glucose. Islets were either stimulated for $90 \mathrm{~min}$ by addition of glucose to $20 \mathrm{mmol} / \mathrm{l}$, or were left for an additional $90 \mathrm{~min}$ in a low glucose medium (unstimulated control). For in vivo stimulation studies, male Lewis rats were injected intravenously with $2 \mathrm{ml}$ of either $1 \mathrm{~mol} / \mathrm{l}$ glucose or saline after overnight starvation. After $90 \mathrm{~min}$, both stimulated and unstimulated animals were injected with cycloheximide $(5 \mathrm{mg} / \mathrm{kg}$, i.p.). Islets were isolated 30 min later. Primary rat liver cells, obtained by in situ collagenase digestion, were grown in defined medium with or without insulin [21]. Human thyroid cells were obtained as surgical specimens of healthy gland adjacent to non-toxic thyroid adenomas and seeded as monolayers in RPMI 1640 containing growth factors (insulin, somatostatin, transferrin, hydrocortisone and glycyl-histidyl-lysine acetate) [22]. After $48 \mathrm{~h}$ in vitro culture, cells were stimulated for 30 min with $1 \mathrm{U} / 1 \mathrm{TSH}$.

RNA isolation and characterization. The MIN6, HIT, RIN or INS-1 cells were glucose deprived $(1,0.1,0.01$ and $1 \mathrm{mmol} / \mathrm{l}$, respectively) for $48 \mathrm{~h}$ and stimulated in a high glucose medium $(20 \mathrm{mmol} / \mathrm{l})$ for $30 \mathrm{~min}$. Alternatively, they were starved for $24 \mathrm{~h}$ and stimulated for $24 \mathrm{~h}$. Stimulation was assessed by insulin RIA of culture supernatants. After washing with PBS, cells were lysed in situ in acid guanidinium phenol [23], and RNA was isolated after chloroform extraction. Total cellular RNA ( $7 \mu \mathrm{g} /$ lane) was fractionated on $1 \%$ agarose gel, and transferred to activated nylon membranes (GeneScreen Plus, New England Nuclear Research Products, Boston, MA., USA). The RNA blots were hybridized overnight with ${ }^{32} \mathrm{P}$-labelled probes. Autoradiographs were quantified by transmission densitometry with a HP4 scanner (Hewlett Packard, Palo Alto, Calif., USA) and SigmaGel software (Jandel Scientific, San Rafarel, CA, USA). The latter method was linear over a range of at least tenfold differences in autoradiographic band intensity.

Subtractive $c D N A$ cloning. Subtracted ${ }^{32} \mathrm{P}$-labelled cDNA probes were synthesized from $2 \mu \mathrm{g}$ polyadenylated RNA [24] from glucose-stimulated or unstimulated MIN6 cells using Su- 
perscript reverse transcriptase (BRL) and $18.5 \mathrm{MBq}^{32} \mathrm{P}-\mathrm{dCTP}$ in each reaction. After alkaline hydrolysis of RNA templates, copy deoxyribonucleic acid (cDNA) probes were hybridized at $65^{\circ} \mathrm{C}$ with $20 \mu \mathrm{g}$ biotinylated mRNA from unstimulated cells (Photobiotin, Vector Laboratories, Burlingame, CA, USA) for $36 \mathrm{~h}$. Biotin-RNA: ${ }^{32} \mathrm{P}-\mathrm{cDNA}$ duplexes were removed with streptavidin. Residual single-stranded ${ }^{32} \mathrm{P}$-cDNA was used to screen a lambda gt10 bacteriophage cDNA library constructed from stimulated ( $20 \mathrm{mmol} / \mathrm{l}$ glucose) MIN6 cell RNA. Duplicate filters were hybridized with probes from stimulated or unstimulated cells, respectively, at $42^{\circ} \mathrm{C}$ for $48 \mathrm{~h}$ in hybridization buffer $[50 \%$ formamide, 6X SSPE $(0.9 \mathrm{~mol} / 1$ $\mathrm{NaCl}, 60 \mathrm{mmol} / \mathrm{l} \mathrm{NaH} \mathrm{PO}_{4}, 6 \mathrm{mmol} / \mathrm{l}$ EDTA, pH 7.4), $10 \%$ dextran sulphate, $1 \%$ SDS, $2 \times$ Denhardt, $100 \mu \mathrm{g} / \mathrm{ml}$ herring testes DNA and $16 \mu \mathrm{g} / \mathrm{ml} \mathrm{rA} \cdot \mathrm{rU})$. Filters were washed with three high stringency washes for $20 \mathrm{~min}$ each at $65^{\circ} \mathrm{C}$ in $0.2 \times \mathrm{SSC}\left(30 \mathrm{mmol} / \mathrm{l} \mathrm{NaCl}, 3 \mathrm{mmol} / 1 \mathrm{C}_{6} \mathrm{H}_{5} \mathrm{O}_{7} \mathrm{Na}_{3}, \mathrm{pH} 7.0\right)$, $1 \%$ SDS, $0.05 \%$ sodium pyrophosphate, and autoradiographed for 3 days. Plaques detected more strongly with the stimulated cell probe than the control probe were selected for further characterization. cDNA inserts were subcloned into pBluescript (Stratagene, La Jolla, CA, USA) and sequenced by the dideoxy-nucleotide chain termination method.

Immunoblotting. Cells were rinsed in PBS, lysed in $2 \times$ SDS loading buffer (125 mmol/l TRIS pH 6.8, $20 \%$ glycerol, $4 \%$ SDS, $10 \%$ 2-mercaptoethanol) and electrophoresed on $8 \%$ SDS-polyacrylamide gel. Proteins were electroblotted to nitrocellulose, incubated with affinity-purified Egr-1 antibody (588 or C-19, Santa Cruz Biotechnology, Santa Cruz, CA) at 1:50 dilution for $1 \mathrm{~h}$, and made visible by autoradiography using ${ }^{125} \mathrm{I}-$ protein A, or by enhanced chemiluminescence (Supersignal Substrate, Pierce, Rockford, Ill., USA) using horseradish peroxidase-conjugated swine-anti-rabbit secondary antibody (1:1000, Dako, Glostrup, Denmark).

\section{Results}

We used subtractive hybridization cloning to identify genes induced by glucose stimulation of the transformed murine beta-cell line, MIN6. These cells closely resemble primary beta cells in several respects [25]. Most importantly, MIN6 cells: (1) synthesize and secrete fully processed insulin in response to physiologic concentrations of glucose $(2-25 \mathrm{mmol} / \mathrm{l})$ [18, $25,26]$; (2) regulate proinsulin synthesis primarily at the translational level [27]; (3) express the GLUT-2 glucose transporter characteristic of islet beta cells and fail to express inappropriately the low $\mathrm{Km}$ 'brain-type' transporter [28]; (4) predominantly use glucokinase to catalyse glucose phosphorylation [28].

Subtracted, ${ }^{32} \mathrm{P}$-labelled cDNA probes enriched for sequences complementary to mRNAs unique to stimulated cells, were used to screen a glucose-stimulated MIN6 cell cDNA library. Out of 66000 recombinant clones screened, 53 representing six different genes were isolated. Four genes encoded enzymes involved in glucose metabolism: triose phosphate isomerase; phosphoglycerate kinase; lactate dehydrogenase; and enolase. Several clones encoding preprodynorphin were isolated [28a]. A single clone encoded
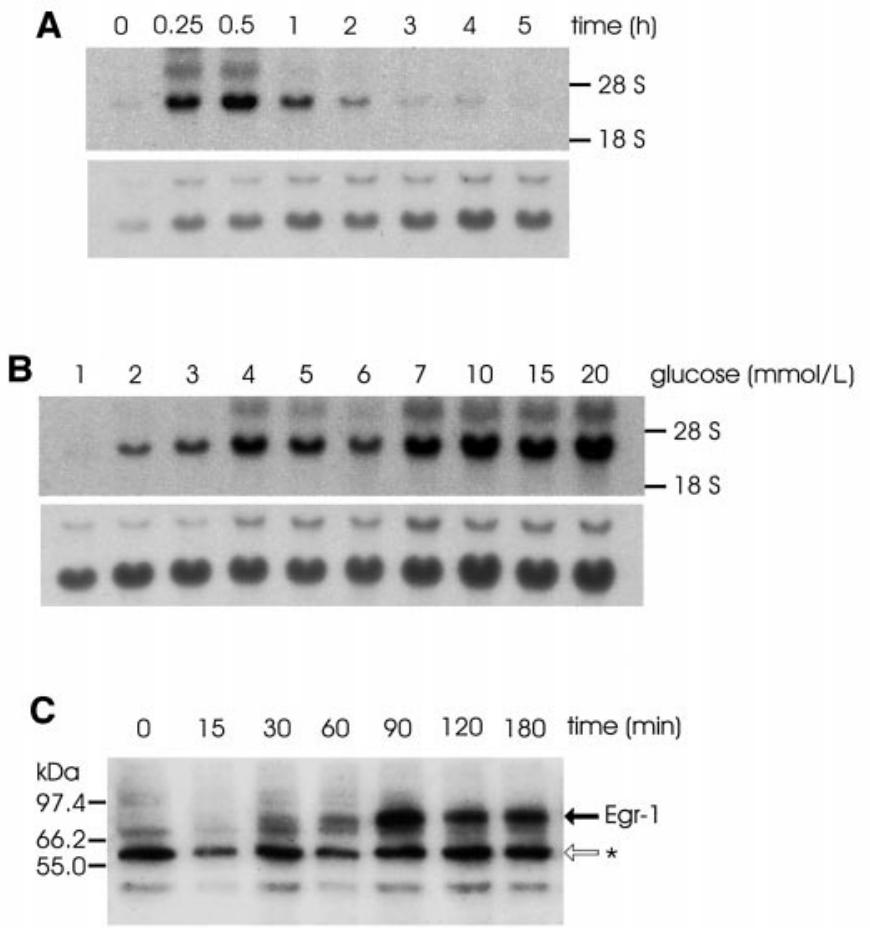

Fig. 1A-C. Induction of early growth response gene-1 by glucose in MIN6 cells. A Time-course of egr-1 mRNA response. After $48 \mathrm{~h}$ glucose-deprivation, cells were stimulated by incubation in medium containing $20 \mathrm{mmol} / \mathrm{l}$ glucose and harvested after the indicated times. RNA was extracted, fractionated on agarose gel and hybridized with ${ }^{32} \mathrm{P}$-labelled murine egr-1 cDNA (upper panel). Positions of rRNA bands are indicated (18 S, $28 \mathrm{~S}$ ). B Magnitude of $e g r-1$ induction is dependent upon stimulatory glucose concentration. After 24-h glucose deprivation, MIN6 cells were incubated in medium containing the indicated glucose concentrations for the next $24 \mathrm{~h}$ (upper panel). Lower panels in $\mathbf{A}$ and $\mathbf{B}$ show respective blots rehybridized to human $\beta$-actin cDNA probe. C Egr-1 protein induction. MIN6 cells were glucose-deprived for $24 \mathrm{~h}$, stimulated with $20 \mathrm{mmol} / \mathrm{l}$ glucose at $\mathrm{t}=0$ and harvested after the indicated times. Proteins were analysed by immunoblot using anti-Egr-1 antibody. Positions of molecular mass standards are indicated on the left. Egr-1 is detected as an $82 \mathrm{kDa}$ protein which first appears at $30 \mathrm{~min}$ post-stimulation. A $59 \mathrm{kDa}$ protein uniformly expressed at all time points is a cross-reactive molecule $(*)$. For results used for quantification in this and the following figures the number of experiments are indicated in Table 1. All other results were confirmed in at least one independent experiment

the zinc-finger transcription factor egr-1 (also called Krox-24, Zif268, NGFI-1; Genbank M28845).

Glucose stimulation of beta cells induces expression of egr-1. Early passage MIN6 cells maintained $48 \mathrm{~h}$ in low glucose $(1.0 \mathrm{mmol} / \mathrm{l})$ medium expressed low or undetectable levels of egr-1 mRNA (Fig. 1A). Within $15 \mathrm{~min}$ after stimulation with $20 \mathrm{mmol} / \mathrm{l}$ glucose, however, egr-1 mRNA expression became detectable and achieved maximum by $30 \mathrm{~min}$. Expression gradually declined thereafter, returning to baseline by $3 \mathrm{~h}$ post-stimulation (Fig. 1A). Despite continous glucose stimulation, the egr-1 mRNA signal did not return 
during the time interval studied $(24 \mathrm{~h})$. The kinetics of $e g r-1$ mRNA accumulation in MIN6 cells after glucose stimulation are identical to those reported previously after anti- $\mu$ activation of murine B lymphocytes and serum stimulation of Balb/c 3T3 fibroblasts [29]. Maximum egr-1 RNA induction in several experiments averaged over 50 -fold as determined by scanning densitometry of autoradiographs.

The magnitude of egr-1 mRNA induction increased in proportion to the stimulatory glucose concentration over a physiologic range from 2 to $20 \mathrm{mmol} / \mathrm{l}$ (Fig. 1B). Previous studies with MIN6 cells [18] and our own observations (data not shown) have indicated graded insulin release over a similar range of glucose concentrations. At high passage numbers ( $>40$ ), MIN6 cells exhibited reduced insulin release in response to glucose and failed to increase egr-1 mRNA expression (data not shown). Together these results suggest that egr-1 induction could be coupled to physiologic mechanisms that regulate specific beta-cell responses to glucose. Importantly, insulin released from stimulated cells was not responsible for this effect, as induction of egr-1 was not detected after addition of exogenous human insulin (see below).

Since Egr-1 expression in many settings is regulated at the translational level $[30,31]$ and expression of several genes in beta cells, including insulin $[5,27]$ and glucokinase [32], is largely regulated translationally, we examined Egr-1 protein expression in glucose-activated cells by immunoblotting using a rabbit polyclonal anti-Egr-1 antibody. The $82 \mathrm{kDa}$ Egr-1 protein accumulated in glucose-activated MIN6 cells with similar but slightly delayed kinetics relative to changes in egr-1 RNA (Fig. 1C). We detected Egr-1 30 min after the shift to high glucose medium, but it did not reach maximum until 90 min post-stimulation. It persisted beyond $3 \mathrm{~h}$, by which time egr-1 RNA levels had already returned to baseline. A similar time course of Egr-1 protein induction has been observed following serum stimulation of Balb/c-3T3 fibroblasts [33].

Glucose also induced egr-1 in other insulin-producing cell lines and in primary pancreatic islets. In glucose-responsive rat INS-1 beta cells, egr-1 mRNA increased within $30 \mathrm{~min}$ after stimulation (Fig.2A). In murine $\beta \mathrm{TC}-3$ beta cells, 30 -min stimulation with glucose failed to increase egr-1 expression above basal level. Cells cultivated continously in high glucose medium, however, expressed egr-1 mRNA at high levels compared with 48-h glucose deprivation (Fig.2A, and data not shown). The RINm5F rat and late-passage HIT-T15 hamster beta-cell lines are generally regarded as non-responsive or responsive in a non-physiological manner $[25,26]$. We found RINm5F cells showed weak induction after $30 \mathrm{~min}$ stimulation or prolonged cultivation in a high glucose medium and HIT-T15 cells were totally unresponsive (Fig. 2A). Insulin RIA measurements of 24-h culture
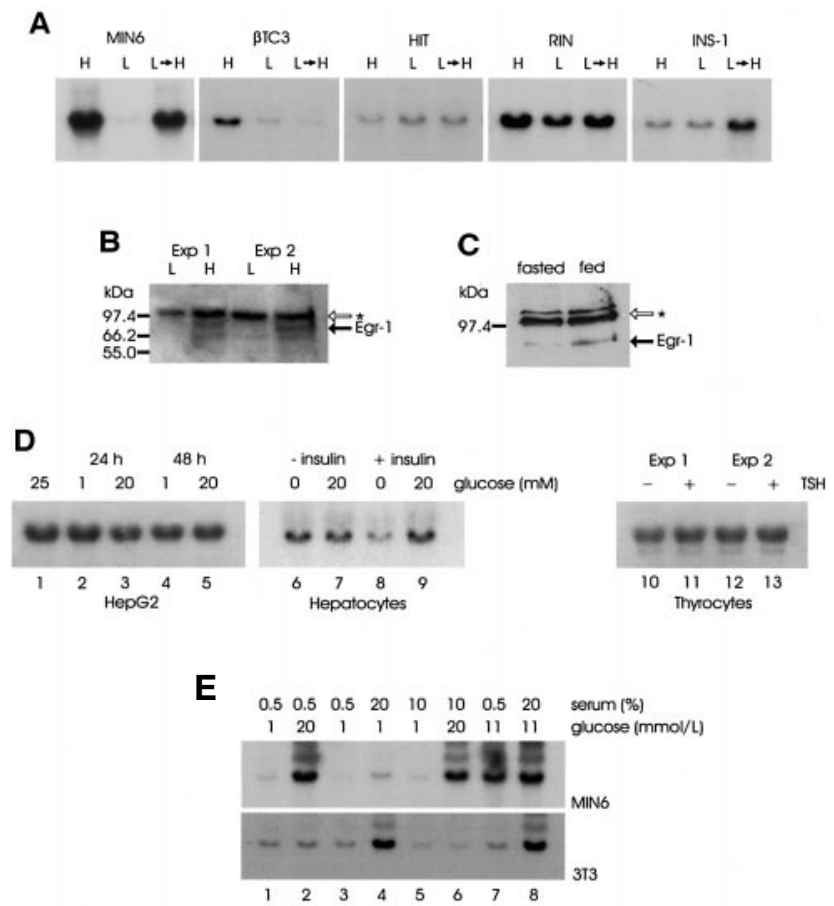

Fig. 2 A-E. egr-1 mRNA expression in beta- and non-betacells. A Expression of egr-1 mRNA in beta-cell lines MIN6, $\beta$ TC3, HIT-T15, RINm5F and INS-1 after continuous cultivation in high glucose $(20 \mathrm{mmol} / \mathrm{l})$ medium $(\mathrm{H}), 48$-h glucosedeprivation (L), and 30-min glucose stimulation after glucosedeprivation (L- $>\mathrm{H})$. Glucose induced egr-1 mRNA expression in glucose-responsive MIN6, INS-1, $\beta$ TC3 and RINm5F cells but minimally affected expression in non-responsive late passage HIT-T15 cells. Loading of equal amounts of RNA was verified by $\beta$-actin hybridization (not shown). B Egr-1 protein expression in primary rat islets of Langerhans ex vivo. After $24 \mathrm{~h}$ in vitro glucose-deprivation, two separate islet cell preparations (Exp 1 and Exp 2, respectively) were stimulated with glucose $(20 \mathrm{mmol} / \mathrm{l})$ for $90 \mathrm{~min}(\mathrm{H})$, or were left unstimulated in low glucose $(2.8 \mathrm{mmol} / \mathrm{l})$ medium (L). Expression of the $82 \mathrm{kDa} E g r-1$ protein is detected only in stimulated cells. The position of a previously described $105 \mathrm{kDa}$ cross-reactive protein, present in all lanes, is indicated (*). C Egr-1 protein induction in vivo. Islets of Langerhans were isolated after cycloheximide infusion from rats fasted over night and injected with either glucose or saline. The $105 \mathrm{kDa}$ cross-reactive protein is indicated (*). D Expression of egr-1 mRNA was not affected by glucose stimulation after glucose deprivation of the human liver cell line HepG2 or of primary rat hepatocytes, or after TSH (1 U/l) stimulation of primary human thyroid cells (actin control hybridization showed a reduced amount of RNA in lane 8). E Egr-1 induction in MIN6 cells is glucose-dependent and serum-independent. Egr-1 expression in glucosedeprived MIN6 cells was induced by stimulation with glucose (lanes 2,6) relative to unstimulated controls (lanes 1,5) under both low serum $(0.5 \%$, lanes 1,2$)$ and high serum $(10 \%$, lanes 5,6 ) conditions. Egr-1 expression was not significantly induced in serum deprived MIN6 cells stimulated with $20 \%$ serum (lanes 4,8$)$ relative to unstimulated controls $(0.5 \%$ serum, lanes 3,7$)$ under either low $(1 \mathrm{mmol} / \mathrm{l}$, lanes 3,4$)$ or high $(11 \mathrm{mmol} / \mathrm{l}$, lanes 7,8$)$ glucose conditions. In the lower panel the same conditions were used to stimulate NIH-3T3 fibroblasts. Serum induced egr-1 expression (lanes 4,8 ) in the presence of either low (lanes 3,4) or high (lanes 7, 8) glucose. Glucose stimulation of NIH-3T3 cells (lanes 2, 6) failed to change egr-1 expression relative to low glucose-treated cells (lanes 1 , $5)$, regardless of the serum concentration 
supernatants showed that these findings correlated with the ability of the various cell lines to secrete insulin in response to glucose. Glucose stimulation ( $20 \mathrm{mmol} / \mathrm{l})$ of $24 \mathrm{~h}$ glucose-deprived MIN6 cells increased the insulin concentrations more than 15-fold $(1070 \pm 104$ vs $17085 \pm 2831 \mathrm{ng} / \mathrm{ml}, n=20, p<0.001$, subsequent values mentioned in this paragraph are measured in the same units). Similar results were obtained for $\beta$ TC3 cells $(2640 \pm 771$ vs $9007 \pm 2213$, $n=8, p=0.006)$. Substantially weaker responses were obtained with INS-1 ( $63 \pm 6$ vs $119 \pm 13, n=5$, $p=0.005)$ and RIN cells $53 \pm 4$ vs $95 \pm 13, n=11$, $p=0.002$ ), whereas stimulation could not be shown for HIT $(125 \pm 39$ vs $65 \pm 14, n=12, p=0.16)$. Together these data indicate that egr-1 induction after glucose stimulation correlates with other variables of glucose-responsiveness.

In primary islets, Egr-1 expression was assessed at the protein level by immunoblot. In isolated rat islets cultured ex vivo in low glucose medium Egr-1 protein was undetectable but it was induced after $90 \mathrm{~min}$ incubation in a high glucose medium (Fig. 2B). To minimize possible artifacts of the isolation procedure or the in vitro cultivation, islets were also isolated from rats injected with the protein synthesis inhibitor, cycloheximide, after overnight starvation and subsequent glucose or saline injection. A protein of 80 $\mathrm{kDa}$ that most likely represents Egr-1 protein was present at higher concentrations in lysates of islets from animals injected with glucose than from control animals (Fig.2C). Although non-beta cells present in the unfractionated islets used in these studies could have contributed to the Egr-1 protein induction, taken together these results strongly suggest that increased Egr-1 expression is a component of the betacell response to glucose in vivo.

Induction of egr-1 by glucose is unique to beta-cells. Expression of egr-1 was not affected by stimulation in any of the non-insulin-producing primary cell explants or cell lines examined. Glucose failed to induce egr-1 expression in glucose-depleted HepG2 human hepatoma cells or primary rat hepatocytes cultured ex vivo either with or without insulin (Fig. 2D). Though HepG2 cells do not synthesize insulin, they are glucose-responsive and increase expression of genes encoding metabolic enzymes, such as fatty acid synthase, after glucose stimulation [34]. Stimulation of primary human thyrocyte cultures [22] with TSH also did not affect egr-1 mRNA expression (Fig. 2D), demonstrating that egr-1 induction is not a general feature of activation, increased intracellular cAMP or exocytosis in other endocrine cell types. Similarly, whereas mitogenic serum stimulation induced egr-1 mRNA in serum-depleted NIH-3T3 fibroblast cultures (sevenfold induction), glucose stimulation of glucose-deprived 3T3 cells failed to affect egr-1 expression (1.5fold induction, Fig. 2E, lower panel). These results show that the effects of glucose on egr-1 expression are highly specific to beta-cells. Interestingly, glucose induction of egr-1 mRNA in primary explanted renal mesangial cells has also been reported [35].

Although egr-1 can be induced by mitogenic stimuli in many cell types, serum stimulation of serum-deprived MIN6 cells elicited minimal induction (threefold, Fig. 2E). In contrast, glucose stimulation resulted in characteristically large increases in egr-1 RNA under both high $(20 \%)$ and low $(0.5 \%)$ serum conditions (greater than 20-fold). Since MIN6 cells failed to proliferate in $0.5 \%$ serum under either high or low glucose conditions, activation of egr-1 expression did not require induction of mitosis.

Glucose induces other immediate early response genes. Expression of other immediate early response genes in MIN6 cells after glucose treatment was examined by RNA blot hybridization. Glucose induced expression of $c$-fos mRNA with kinetics similar to egr-1 message accumulation (Fig. 3A). Maximum $c$ fos mRNA expression was reached 15 to $30 \mathrm{~min}$ after stimulation and declined rapidly thereafter to baseline by 1 to $2 \mathrm{~h}$. Similar kinetics of $c$-fos mRNA accumulation have been shown after stimulation with mitogens [36]. Glucose also induced junB mRNA, but did not affect expression of junD or $c$-jun, which were expressed constitutively at readily detectable levels (Fig. 3A). The latter result is consistent with previous studies showing high constitutive $c$-jun expression in beta cells in the absence of glucose and reduced expression after glucose treatment [37]. As was observed for egr-1, prolonged cultivation in a high glucose medium also resulted in constitutive, high expression of both junB (Fig. 3A, lane $\mathrm{H}$ ) and $c$-fos (data not shown).

Regulation of egr-1 induction. Intracellular signals involved in early growth response gene induction were analysed using pharmacologic agents. Results of these studies are summarized in Table 1. Though insulin induces egr-1 expression in several cell types [38], it did not alter the expression of egr-1 mRNA in MIN6 cells (Fig. 3B), even when added in concentrations up to 10 times higher than those achieved in post-stimulatory culture supernatants. These results rule out autocrine insulin stimulation as a mechanism for egr-1 induction. Treating MIN6 cells with membrane depolarizing agents, arginine or potassium chloride, induced egr-1 mRNA to levels comparable to induction by glucose (Fig. 3B, Table 1). As with glucose-stimulated insulin release, egr-1 induction was largely inhibited by EDTA and thus appears to be dependent upon influx of extracellular $\mathrm{Ca}^{2+}$ (Fig.3C). Treating MIN6 cells with the $\mathrm{Ca}^{2+}$-ionophore, ionomycin, did not, however, increase egr-1 mRNA expression (Fig. 3B), indicating that $\mathrm{Ca}^{2+}$ influx alone is insufficient to induce egr-1. 
A
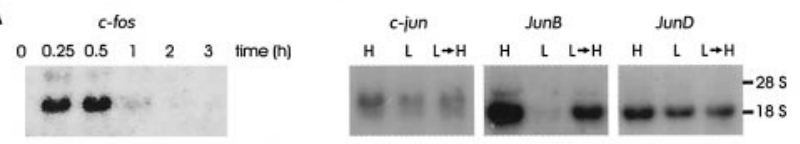

B
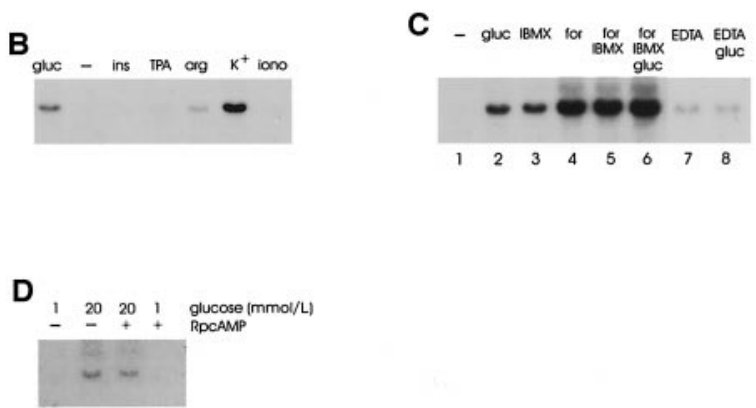

Fig.3 A-D. Stimulation of early growth response genes by glucose and secretagogues. A Glucose stimulation of early growth response genes. Expression of $c$-fos mRNA increased to maximum within 15 to 30 min after stimulation of glucose-deprived MIN6 cells and declined rapidly thereafter. Expression of junB was also induced by 30 min glucose stimulation of glucose-deprived MIN6 cells or by continuous cultivation in high glucose medium (lane $\mathrm{H}$ ). Expression of $c$-jun and junD were unaffected by transient stimulation with glucose (lane $\mathrm{L}->\mathrm{H}$ ) or continuous high glucose cultivation (lane $\mathrm{H}) . \mathrm{H}, \mathrm{L}$ and $\mathrm{L}->\mathrm{H}$ refer to stimulation conditions as in Fig. 2A. B-D Effects of pharmacologic agents and insulin secretagogues on egr-1 mRNA expression. After $48 \mathrm{~h}$ culture in low glucose medium, MIN6 cells were treated for $30 \mathrm{~min}$ with the indicated agents. Concentrations for each agent are indicated in Table 1. EDTA $(\mathbf{C}$, lane 8) and Rp-cAMPS (D) were added 30 min prior to addition of glucose

Activation of protein kinase $\mathrm{C}$ by TPA did not increase egr-1 mRNA. Treating cells with TPA for 30 min prior to glucose stimulation, however, potentiated the effects of glucose (Table 1). Down-regulating protein kinase $\mathrm{C}$ by $24-\mathrm{h}$ incubation with TPA did not appreciably reduce the response to glucose (Table 1). Previous studies have shown that protein kinase $\mathrm{C}$ activation augments, but is not necessary for, glucose-induced insulin secretion [39]. Similarly, treating MIN6 cells with the phosphatase inhibitor, okadaic acid, did not alter egr-1 expression, but potentiated egr-1 induction by glucose (Table 1). Together these results suggest an important role for protein phosphorylation in modifying transcriptional responses to glucose stimulation.

Finally, IBMX and forskolin, stimulators of the cAMP system, both induced egr-1 mRNA in the absence of glucose (Fig. 3C). The magnitude of induction with each drug individually was on average sevenfold higher than standard induction with glucose (Table 1). In combination, IBMX and forskolin induced egr-1 synergistically (Fig $3 \mathrm{C}$, Table 1 ). These agents in combination also strongly potentiated the effects of glucose, inducing a 40-fold greater increase in egr-1 mRNA than glucose alone (Fig. 3C, Table 1). A competitive cAMP inhibitor, Rp-cAMPS, did not,
Table 1. Induction of egr-1 mRNA expression after 30-min stimulation of glucose-deprived MIN6 cells with various secretagogues, quantification of egr-1 expression was by transmission densitometry on autoradiographs of RNA blots. Induction ratios were calculated by dividing egr-1 signal intensity for each secretagogue by the signal intensity for the $20 \mathrm{mmol} / \mathrm{l}$ glucose stimulation standard included with each experiment. The average number of $(n)$ separate stimulation/hybridization experiments is indicated

\begin{tabular}{|c|c|c|}
\hline Compound & $\begin{array}{l}\text { Induction } \\
\text { ratio } \\
\text { Means } \pm \text { SEM }\end{array}$ & $n$ \\
\hline $\begin{array}{l}\text { Glucose-deprived: } 24 \mathrm{~h}, 1 \mathrm{mmol} / 1 \text { glucose } \\
\text { Glucose } 20 \mathrm{mmol} / 1 \\
\text { Insulin } 0.3 \mathrm{U} / \mathrm{ml}\end{array}$ & $\begin{array}{l}0.02 \pm 0.04 \\
1.0 \\
0.0 \pm 0.0\end{array}$ & $\begin{array}{r}10 \\
15 \\
6\end{array}$ \\
\hline $\begin{array}{l}\text { IBMX } 100 \mu \mathrm{mol} / 1 \\
\text { Forskolin } 10 \mu \mathrm{mol} / 1 \\
\text { IBMX } 100 \mu \mathrm{mol}+\text { forskolin } 10 \mu \mathrm{mol} / 1 \\
\text { IBMX } 100 \mu \mathrm{mol}+\text { forskolin } 10 \mu \mathrm{mol} / 1+ \\
\text { Glucose } 20 \mathrm{mmol} / 1 \\
\text { Rp-cAMPS } 100 \mu \mathrm{mol} / 1+\text { glucose } 20 \mathrm{mmol} / 1\end{array}$ & $\begin{aligned} 6.9 & \pm 5.4 \\
7.0 & \pm 4.0 \\
10.0 & \pm 4.4 \\
40.3 & \pm 17.0\end{aligned}$ & $\begin{array}{l}3 \\
3 \\
7 \\
3\end{array}$ \\
\hline $\begin{array}{l}\text { Arginine } 20 \mathrm{mmol} / \mathrm{l} \\
\mathrm{K}^{+} 25 \mathrm{mmol} / \mathrm{l}\end{array}$ & $\begin{array}{l}0.4 \pm 0.1 \\
1.8 \pm 1.0\end{array}$ & $\begin{array}{l}4 \\
4\end{array}$ \\
\hline $\begin{array}{l}\text { Ionomycin } 1 \mu \mathrm{mol} / \mathrm{l} \\
\text { EDTA } 10 \mathrm{mmol} / \mathrm{l} \\
\text { EDTA } 10 \mathrm{mmol} / 1+\text { glucose } 20 \mathrm{mmol} / 1\end{array}$ & $\begin{array}{l}0.2 \pm 0.1 \\
0.1 \pm 0.1 \\
0.3 \pm 0.2\end{array}$ & $\begin{array}{l}4 \\
2 \\
3\end{array}$ \\
\hline $\begin{array}{l}\text { TPA } 10 \mathrm{nmol} / 1 \\
\text { TPA } 10 \mathrm{nmol} / 1,30 \mathrm{~min}+\text { glucose } 20 \mathrm{mmol} / 1 \\
\text { TPA } 100 \mathrm{nmol} / 1,24 \mathrm{~h}+\text { glucose } 20 \mathrm{mmol} / 1\end{array}$ & $\begin{aligned} 0.2 & \pm 0.1 \\
28.6 & \pm 21.7 \\
2.8 & \pm 1.7\end{aligned}$ & $\begin{array}{l}9 \\
2 \\
2\end{array}$ \\
\hline $\begin{array}{l}\text { Okadaic acid } 1 \mu \mathrm{mol} / 1 \\
\text { Okadaic acid } 1 \mu \mathrm{mol} / 1+\text { glucose } 20 \mathrm{mmol} / 1\end{array}$ & $\begin{array}{l}0.2 \pm 0.2 \\
3.7 \pm 1.2\end{array}$ & $\begin{array}{l}2 \\
4\end{array}$ \\
\hline
\end{tabular}

however abolish the stimulatory effect of glucose (Fig. 3D), showing that cAMP signalling pathways can potentiate but are not essential for glucose-induced egr-1 mRNA accumulation.

\section{Discussion}

These experiments show that glucose stimulation of beta cells induces expression of the immediate early growth response genes egr-1, c-fos and junB. Expression of $c$-jun was not induced in MIN6 cells, in agreement with previous studies showing down-regulation of $c$-jun in HIT beta cells by glucose [37]. Induction of egr-1 correlated with insulin secretory capacity and was not observed in thyrocytes stimulated with thyrotropin or in glucose-treated hepatocytes. Among beta-cell lines, egr-1 was strongly induced in highly glucose-responsive MIN6 and $\beta$ TC 3 lines and in INS-1 cells, least induced in weakly responsive RINm5F cells $[25,26]$, and was not induced detectably in late passage MIN6 and HIT-T15 cells, which fail to secrete insulin in response to glucose [16]. Importantly, Egr-1 protein was also induced in primary islets stimulated either in vivo or in vitro. These results argue that immediate early gene activation is a unique and fundamental aspect of the beta-cell response to glucose. 
Although immediate early growth response genes are typically induced by stimuli that promote mitosis $[29,36,40]$, their induction by glucose is independent of the beta-cell proliferative state. Glucose increased egr-1 expression under low serum conditions which do not support proliferation of MIN6 cells, whereas serum stimulation of serum-deprived MIN6 cells induced egr-1 expression only weakly. Moreover, mitogenic stimuli characteristically induce $c$-jun coordinately with $c$-fos and junB [36, 40, 41], whereas glucose did not alter $c$-jun expression. Failure to activate $c$-jun is probably an important aspect of the unique beta-cell response to glucose since c-Jun represses insulin gene transcription [37].

The correlation between egr-1 induction and insulin secretion suggests that shared or overlapping intracellular signalling pathways regulate these two responses. During beta-cell stimulation, products of glucose metabolism initiate secondary signals that trigger closure of ATP-sensitive $\mathrm{K}^{+}$-channels, depolarization of beta-cell membranes and opening of voltage-sensitive, L-type $\mathrm{Ca}^{2+}$-channels [26]. The resulting increase in intracellular $\mathrm{Ca}^{2+}{ }_{-}$ion concentration causes insulin release. In this light it is of relevance that egr-1 expression was both dependent on $\mathrm{Ca}^{2+}$-influx and inducible by membrane depolarizing agents.

Recent observations indicate that glucose stimulation could be linked to immediate early gene induction through $\mathrm{Ca}^{2+}$-dependent activation of mitogenactivated protein (MAP) kinases. Transcription of $c$ fos and egr-1 is initiated by phosphorylation of serum response element (SRE)-binding proteins such as Elk-1 by activated MAP kinases [42, 43]. In INS-1 beta cells, 44-kDa MAP kinase is activated after either glucose stimulation, membrane depolarization or treatment with insulin secretagogues [44]. Depolarization of $\mathrm{PC} 12$ pheochromocytoma cell membranes similarly causes $\mathrm{Ca}^{2+}$-dependent activation of MAP kinases and induces expression of immediate early genes egr-1, $c$-fos, and junB but does not affect $c$-jun expression [45]. These results suggest that MAP kinase activation and immediate early gene induction are consistent features of neuroendocrinecell activation after membrane depolarization. The role of these kinases in specific beta-cell responses to glucose is, however, not clear since activation of 44-kDa MAP kinase alone is not sufficient to cause insulin release [46, 47].

In addition to triggering beta-cell insulin release, glucose also alters expression of a number of genes, including those encoding insulin, the GLUT-2 glucose transporter [6], and various glucose metabolic enzymes such as acetyl-coenzyme A-carboxylase [8] and pyruvate kinase [7]. In concert, these changes could be necessary for beta-cell adaptation to the increased metabolic and secretory demands of a high glucose environment. Immediate early response proteins could serve an important function in this process by altering expression of specific target genes in response to metabolic changes. The egr-1 encodes a zinc-finger protein of the $\mathrm{Cys}_{2}-\mathrm{His}_{2}$ subfamily that regulates transcription through redox-dependent binding to the consensus DNA sequence 5'GCGGGGGCG-3' [48, 49]. The $c$-fos gene product associates with Jun proteins to form stable AP1 heterodimers. Sequence-specific DNA binding by AP-1 factors is also dependent on reduction at cysteine residues in Fos and Jun components [50]. Since glucose stimulation of beta cells increases cytoplasmic flavin adenine dinucleotide [reduced form] $\left(\mathrm{FADH}_{2}\right)$ and NADH reducing potential [51], glucose metabolism could be coupled to transcriptional activation by Egr-1 and AP-1 factors.

The possibility that Egr-1 has a central role in regulating beta-cell responses to glucose is supported by close sequence similarities between Egr-1 and transcription factors that control carbohydrate metabolism in yeast. Multicopy inhibitor of GAL1 promoter (MIG1p) is a $\mathrm{Cys}_{2}-\mathrm{His}_{2}$ zinc-finger protein of Saccharomyces cerevisiae which shares $68 \%$ amino acid identity in its zinc-finger region with Egr- 1 and binds to GC-rich target sequences that closely resemble the Egr-1 consensus binding site [52]. MIG1 p is responsible for glucose-repression of $G A L 1$, which encodes galactase and of GAL4 [52]. The proteins encoded by multicopy suppressor of snf $(M S N) 2$ and MSN4 [53] of S. cerevesiae share $60 \%$ and $52 \%$ identity, respectively, with the Egr-1 zinc-finger region and are necessary for metabolic stress responses and for glucose-induced derepression of the alcohol dehydrogenase gene $\mathrm{ADH}_{2}$.

Though egr-1 expression is induced in many mammalian cell types after a variety of external stimuli, few genes specifically regulated by Egr-1 have been identified. Moreover, effects on individual target genes are largely cell-type-specific, implying that Egr-1 acts in concert with other transcription factors whose expression or activity is highly restricted [31]. In fibroblasts, Egr-1 activates expression of thymidine kinase after serum stimulation [54], whereas in endothelial cells Egr-1 upregulates platelet-derived growth factor B-chain expression after mechanical injury [55]. In B lymphocytes, Egr-1 activates expression of genes encoding the intercellular adhesion molecules ICAM-1 [56] and CD44 [57]. Genes regulated by Egr-1 in beta cells are currently not known. The Egr-1 consensus sequence has, however, been identified in promoters of several genes that could be involved in beta-cell function. These include genes encoding the beta-cell-specific $\alpha_{1}$ subunit of the Ltype voltage-dependent $\mathrm{Ca}^{2+}$ channel $\left(\mathrm{VDCC}_{1}\right)$, slow sarcoplasmic reticulum $\mathrm{Ca}^{2+}$-ATPase, calcineurin, the cAMP response element binding protein, $\mathrm{Na}^{+} / \mathrm{K}^{+}$-ATPase $\alpha 1$ subunit (NKAA1) and aldolase. Interestingly, aldolase mRNA is upregulated in MIN6 cells after glucose stimulation (unpublished 
observation). Experiments are in progress to determine whether expression of any other of these genes is altered after glucose stimulation.

In endocrine cells Egr-1 induction has not been described previously. Its role in closely related neuronal cells has, however, been studied intensively and could be relevant. Both $c$-fos and $e g r-1$ are induced in neurons after repetitive depolarization and are essential to adaptive long-term potentiation [58]. Specific transcriptional targets for Egr-1 include genes encoding synaptic vesicle transport proteins synapsins I and II [59]. Beta cells resemble neurons in several respects including activation by membrane depolarization, voltage-dependent $\mathrm{Ca}^{2+}$ influx and regulated release of intracytoplasmic vesicle contents via exocytosis. Expression of neuroendocrine-specific transcriptional activators (Islet-1, Pax-6 and Beta2) and neuronrestrictive silencer factor / repressor element silencing transcription (NRSF/REST) in both cell types [60] indicates close similarities in gene regulation. Beta cells also exhibit plasticity and modulate insulin release according to previous glucose exposure. Together, these findings suggest that immediate early response proteins could modulate transcription of genes which are necessary for long-term potentiation or adaptive changes in beta-cell function.

Acknowledgements. We thank J.-I. Miyazaki, Tokyo, S. Efrat, New York, R.F. Santerre, Indianapolis and C.B. Wollheim, Geneva for MIN6, $\beta$ TC3, HIT and INS-1 cells. We are grateful to Å. K. Rasmussen, The University Hospital, N. Grunnet, Panum Instituttet and M. Johnsen, University of Copenhagen, Copenhagen for providing thyrocytes, primary rat hepatocytes and $c$-fos, $c$-jun, jun-B and jun-D cDNA probes, respectively. The study was supported by the Danish Medical Research Council, The Dagmar Marshall Foundation and The Denmark - America Foundation.

\section{References}

1. Ashcroft SJH (1980) Glucoreceptor mechanisms and the control of insulin release and biosynthesis. Diabetologia 18: $5-15$

2. Itoh N, Okamoto H (1980) Translational control of proinsulin synthesis by glucose. Nature 283: 100-102

3. Welsh M, Nielsen DA, MacKrell AJ, Steiner DF (1985) Control of insulin gene expression in pancreatic beta-cells and in an insulin-producing cell line, RIN-F cells. II Regulation of insulin mRNA stability. J Biol Chem 260: 13590-13594

4. Clark SA, Burnham BL, Chick WL (1990) Modulation of glucose-induced insulin secretion from a rat clonal betacell line. Endocrinology 127: 2779-2788

5. Nielsen DA, Welsh M, Casadaban MJ, Steiner DF (1985) Control of insulin gene expression in pancreatic beta-cells and in an insulin-producing cell line, RIN-F cells. I. Effects of glucose and cAMP on the transcription of insulin mRNA. J Biol Chem 260: 13585-13589

6. Yasuda K, Yamada Y, Inagaki N et al. (1992) Expression of GLUT1 and GLUT2 glucose transporter isoforms in rat islets of Langerhans and their regulation by glucose. Diabetes 41: 76-81
7. Marie S, Diaz-Guerra MJ, Miquerol L, Kahn A, Iynedjian PB (1993) The pyruvate kinase gene as a model for studies of glucose-dependent regulation of gene expression in the endocrine pancreatic beta-cell type. J Biol Chem 268: 23881-23890

8. Brun T, Roche E, Kim KH, Prentki M (1993) Glucose regulates acetyl-CoA carboxylase gene expression in a pancreatic beta-cell line (INS-1). J Biol Chem 268: 18905-18911

9. Björk E, Kämpe O, Karlsson FA et al. (1992) Glucose regulation of the autoantigen GAD65 in human pancreatic islets. J Clin Endocrinol Metab 75: 1574-1576

10. Marshak S, Totary H, Cerasi E, Melloul D (1996) Purification of the beta-cell glucose-sensitive factor that transactivates the insulin gene differentially in normal and transformed islet cells. Proc Natl Acad Sci USA 93: 15057-15062

11. German MS, Wang J (1994) The insulin gene contains multiple transcriptional elements that respond to glucose. Mol Cell Biol 14: 4067-4075

12. Sharma A, Stein R (1994) Glucose-induced transcription of the insulin gene is mediated by factors required for betacell-type-specific expression. Mol Cell Biol 14: 871-879

13. MacFarlane WM, Read ML, Gilligan M, Bujalska I, Docherty K (1994) Glucose modulates the binding activity of the beta-cell transcriptioin factor IUF1 in a phosphorylationdependent manner. Biochem J 303: 625-631

14. Zhang S, Kim KH (1997) Protein kinase CK2 down-regulates glucose-activated expression of the acetyl-CoA carboxylase gene. Arch Biochem Biophys 338: 227-232

15. Zangen DH, Bonner-Weir W, Lee CH et al. (1997) Reduced insulin, GLUT2, and IDX-1 in beta cells after partial pancreatectomy. Diabetes 46: 258-264

16. Sharma A, Olson LK, Robertson RP, Stein R (1995) The reduction of insulin gene transcription in HIT-T15 beta cells chronically exposed to high glucose concentration is associated with the loss of RIPE3b1 and STF-transription factor expression. Mol Endocrinol 9: 1127-1134

17. Tokuyama Y, Sturis J, DePaoli AM et al. (1995) Evolution of beta-cell dysfunction in the male Zucker diabetic fatty rat. Diabetes 44: 1447-1457

18. Miyazaki J, Araki K, Yamato E et al. (1990) Establishment of a pancreatic beta cell line that retains glucose-inducible insulin secretion: Special reference to expression of glucose transporter isoforms. Endocrinology 127: 126-132

19. Asfari M, Janjic D, Meda P, Li G, Halban PA, Wollheim CB (1992) Establishment of 2-mercaptoethanol differentiated insulin-secreting cell lines. Endocrinology 130: 167-178

20. Santerre RF, Cook RA, Crisel RM et al. (1981) Insulin synthesis in a clonal cell line of simian virus 40-transformed hamster pancreatic beta cells. Proc Natl Acad Sci USA 78: 4339-4343

21. Dich J, Grunnet N (1990) Primary cultures of rat hepatocytes. Methods Mol Biol 5: 161-176

22. Rasmussen ÅK, Kayser L, Perrild H, Brandt M, Beck K, Feldt-Rasmussen U (1996) Human thyroid epithelial cells cultured in monolayers. I. Decreased thyroglobulin and cAMP response to TSH in 12-week-old secondary and tertiary cultures. Mol Cell Endocrinol 116: 165-172

23. Chomczynski P, Sacchi N (1987) Single-step method of RNA isolation by acid guanidinium thiocyanate phenol chloroform extraction. Anal Biochem 162: 156-159

24. Sambrook J, Fritsch EF, Maniatis T (1989) Molecular cloning. A laboratory manual, 2nd edn. Cold Spring Harbor Laboratory Press, Cold Spring Harbor

25. Poitout V, Olson LK, Robertson RP (1996) Insulin-secreting cell lines: classification, characteristics and potential applications. Diabetes Metab 22: 7-14 
26. Newgard CB, McGarry JD (1995) Metabolic coupling factors in pancreatic beta cell signal transduction. Ann Rev Biochem 64: 689-719

27. Skelly RH, Schuppin GT, Ishihara H, Oka Y, Rhodes CJ (1996) Glucose-regulated translational control of proinsulin biosynthesis with that of the proinsulin endopeptidases PC2 and PC3 in the insulin-processing MIN6 cell line. Diabetes 45 : $37-43$

28. Ishihara H, Asano T, Tsukuda K et al. (1993) Pancreatic beta cell line MIN6 exhibits characteristics of glucose metabolism and glucose-stimulated insulin secretion similar to those of normal islets. Diabetologia 36: 1139-1145

28 a. Josefsen K, Buschard K, Sørensen LR et al. (1998) Glucose stimulation of pancreatic $\beta$-cells lines induces expression and secretion of dynorphin. Endocrinology 139: 4329-4336

29. Sukhatme VP, Kartha S, Toback FG, Taub R, Hoover RG, Tsai-Morris CH (1987) A novel early growth response gene rapidly induced by fibroblast, epithelial cell and lymphocyte mitogens. Oncogene Res 1: 343-355

30. Cao XM, Guy GR, Sukhatme VP, Tan YH (1992) Regulation of the Egr-1 gene by tumor necrosis factor and interferons in primary human fibroblasts. J Biol Chem 267: $1345-1349$

31. Gashler A, Sukhatme VP (1995) Early growth response protein 1 (EGR-1): prototype of a zinc-finger family of transcription factors. Prog Nucleic Acid Res Mol Biol 50: 191-224

32. Liang Y, Najafi H, Smith RM et al. (1992) Concordant glucose induction of glucokinase, glucose usage, and glucosestimulated insulin release in pancreatic islets maintained in organ culture. Diabetes 41: 792-806

33. Cao XM, Koski RA, Gashler A et al. (1990) Identification and characterization of the Egr-1 gene product, a DNAbinding zinc finger protein induced by differentiation and growth signals. Mol Cell Biol 10: 1931-1939

34. Semenkovich CF, Coleman T, Goforth R (1993) Physiologic concentrations of glucose regulate fatty acid synthase activity in HepG2 cells by mediating fatty acid synthase mRNA stability. J Biol Chem 268: 6961-6970

35. Wolf G, Sharma K, Chen Y, Ericksen M, Ziyadeh FN (1992) High glucose-induced proliferation in mesangial cells is reversed by autocrine TGF-beta. Kidney Int 42: 647-656

36. Lau LF, Nathans D (1987) Expression of a set of growth-related immediate early genes in BALB/c 3T3 cells: coordinate regulation with c-fos or c-myc. Proc Natl Acad Sci USA 84: 1182-1186

37. Inagaki N, Maekawa T, Sudo T, Ishii S, Seino Y, Imura H (1992) c-Jun represses the human insulin promotor activity that depends on multiple cAMP response elements. Proc Natl Acad Sci USA 89: 1045-1049

38. Alexander-Bridges M, Buggs C, Giere L et al. (1992) Models of insulin action on metabolic and growth response genes. Mol Cell Biochem 109: 99-105

39. Arkhammar P, Nilsson T, Welch M, Welch N, Berggren PO (1989) Effects of protein kinase C activation on the stimulus-secretion coupling in pancreatic beta-cells. Biochem $\mathrm{J}$ 264: 207-215

40. Quantin B, Breathnach R (1988) Epidermal growth factor stimulates transcription of the c-jun proto-oncogene in rat fibroblasts. Nature 334: 538-539

41. Bartel DP, Sheng M, Lau LF, Greenberg ME (1989) Growth factors and membrane depolarization activate distinct programs of early response gene expression: dissociation of fos and jun induction. Genes Dev 3: 304-313

42. Marais R, Wynne J, Treisman R (1993) The SRF accessory protein Elk-contains a growth factor-regulated transcriptional activation domain. Cell 73: 381-393
43. Hipskind RA, Baccarini M, Nordheim A (1994) Transient activation of RAF-1, MEK, and ERK2 coincides kinetically with ternary complex factor phosphorylation and immediate-early gene promoter activity in vivo. Mol Cell Biol 14: 6219-6231

44. Frodin M, Sekine N, Roche E et al. (1995) Glucose, other secretagogues, and nerve growth factor stimulate mitogenactivated protein kinase in the insulin-secreting beta-cell line, INS-1. J Biol Chem 270: 7882-7889

45. Rosen LB, Ginty DD, Weber MJ, Greenberg ME (1994) Membrane depolarization and calcium influx stimulate MEK and MAP kinase via activation of Ras. Neuron 12: 1207-1221

46. Khoo S, Cobb MH (1997) Activation of mitogen-activating protein kinase by glucose is not required for insulin secretion. Proc Natl Acad Sci USA 94: 5599-5604

47. Persaud SJ, Wheeler-Jones CP, Jones PM (1996) The mitogen-activated protein kinase pathway in rat islets of Langerhans: studies on the regulation of insulin secretion. Biochem J 313: 119-124

48. Madden SL, Rauscher F (1993) Positive and negative regulation of transcription and cell growth mediated by the EGR family of zinc-finger gene products. Ann NY Acad Sci 684: $75-84$

49. Huang RP, Adamson ED (1993) Characterization of the DNA-binding properties of the early growth response-1 (egr-1) transcription factor: evidence for modulation by a redox mechanism. DNA Cell Biol 12: 265-273

50. Abate C, Patel L, Rauscher FJ3, Curran T (1990) Redox regulation of fos and jun DNA-binding activity in vitro. Science 249: 1157-1161

51. Dukes ID, McIntyre MS, Mertz RJ et al. (1994) Dependence on NADH produced during glycolysis for beta-cell glucose signaling. J Biol Chem 269: 10979-10982

52. Nehlin JO, Ronne H (1990) Yeast MIG1 repressor is related to the mammalian early growth response and Wilms' tumour finger proteins. EMBO J 9: 2891-2898

53. Estruch F, Carlson M (1993) Two homologous zinc finger genes identified by multicopy suppression in a SNF1 protein kinase mutant of Saccharomyces cerevisiae. Mol Cell Biol 13: 3872-3881

54. Molnar G, Crozat A, Pardee AB (1994) The immediate early gene Egr-1 regulates the activity of the thymidine kinase promotor at the G0-to-G1 transition of the cell cycle. Mol Cell Biol 14: 5242-5248

55. Khachigian LM, Lindner V, Williams AJ, Collins T (1996) Egr-1-induced endothelial gene expression: a common theme in vascular injury. Science 271: 1427-1431

56. Maltzman JS, Carman JA, Monroe JG (1996) Transcriptional regulation of the ICAM-q gene in antigen receptorand phorbol ester-stimulated B lymphocytes: role for transcription factor EGR-1. J Exp Med 183: 1747-1759

57. Maltzman JS, Carman JA, Monroe JG (1996) Role of EGR1 in regulation of stimulus-dependent CD44 transcription in B lymphocytes. Mol Cell Biol 16: 2283-2294

58. Abraham WC, Dragunow M, Tate WP (1991) The role of immediate genes in the stabilization of long-term potentiation. Mol Neurobiol 5: 297-314

59. Petersohn D, Schoch S, Brinkmann DR, Thiel G (1995) Possible role for the transcription factor zif286/egr-1, polyoma enhancer activator 3, and AP-2. J Biol Chem 270: 24361-24369

60. Atouf F, Czernichow P, Scharfmann R (1997) Expression of neuronal traits in pancreatic beta cells. Implication of neuron-restrictive silencing factor/repressor element silencing transcription factor, a neuron-restrictive silencer. J Biol Chem 272: 1929-1934 